\title{
TPM3/NTRK1 Fusion Gene
}

National Cancer Institute

\section{Source}

National Cancer Institute. TPM3/NTRK1 Fusion Gene. NCI Thesaurus. Code C99386.

A fusion gene ( $2.3 \mathrm{~kb})$ that results from a cryptic rearrangement of chromosome $1 \mathrm{q}$ that fuses most of the coding sequence for the TPM3 gene to the 3 ' portion of the NTRK1 gene. This rearrangement is associated with papillary thyroid carcinoma. 